\title{
DEVELOPMENTAL TAXONOMY OF CONDUCT DISORDER
}

\author{
Jelena Kostić ${ }^{1}$ Milkica Nešić ${ }^{2}$ Jasminka Marković ${ }^{3}$ \\ Miodrag Stanković ${ }^{1}$
}

\begin{abstract}
Conduct disorder is a heterogeneous disorder in terms of etiology, course and prognosis, and currently, there is no singular model that would describe the development of the disorder. The results of empirical research on males confirm this heterogeneity, as they point out to two possible developmental pathways: childhood-onset and adolescentonset type. This paper presents the basic elements of developmental taxonomic theory which argues that there are two different developmental pathways to conduct disorder which have different causes and serve as the basis for the current typology of conduct disorders in the classification systems. Such a typology of conduct disorders in the diagnostic classification allows better understanding, prognosis and choice of treatment. Acta Medica Medianae 2015;54(4):79-83.
\end{abstract}

Key words: conduct disorder, children, adolescents

Clinic for Mental Health Protection, Department for child and adolescent psychiatry, Clinical Centre Niš ${ }^{1}$

University of Niš, Faculty of Medicine, Institute of Physiology ${ }^{2}$

Centre for Child and Adolescent Psychiatry, Institute of

Psychiatry, Clinical Centre of Vojvodina, Novi Sad ${ }^{3}$

Contact: Jelena Kostić

Clinic for Mental Health Protection

Clinical Center Niš, 18000 Niš, Serbia

Blv. Zoran Đinđic 48, 18000 Niš, Serbia

E-mail: jelenakostic73@gmail.com

\section{Introduction}

Persistent and frequent antisocial, defiant and delinquent behavior in children and adolescents up to the age of 18 is classified as conduct disorder $(1,2)$.

According to ICD-X (1), behavioral disorder is characterized by a repetitive and persistent pattern of antisocial, aggressive, and provocative behavior. When such behavior is manifested in its most extreme form, it represents more serious violations than those which are socially expected at a given age and is therefore more serious than ordinary children's mischief or adolescent rebeIlion. Examples of such behavior include: excessive beating and intimidation; cruelty to people or animals; intense destructiveness to property; arson, theft; repeated lying; truancy and running away from home; unusually severe and frequent temper tantrums; defiant provocative behavior, disobedience and insolence. All these forms of behavior, if accentuated, can be sufficient for a diagnosis only if it is repeated over a period of time (at least 6 months).

ICD-X distinguishes several types of behavioral disorders: Conduct disorder confined to the family context, when antisocial behavior is confined to interactions with family members; unsocialized conduct disorder, antisocial behavior is associated with a lack of integration in the peer group, close friendships and empathic relationships with peers; socialized conduct disorder, antisocial behavior occurs in individuals who are generally well integrated into their peer group and is related to the individual's association with a delinquent peer group; Oppositional defiant dis-order, characterized by markedly disobedient and provocative behavior without any serious anti-social or aggressive acts, occurring in children younger than 9 or 10.

According to DSM-IV (2), conduct disorder is defined as "a repetitive and persistent pattern of behavior in which the basic rights of others or basic societal norms or rules are violated", as manifested by the presence of at least three of the 15 criteria in the past 12 months, with at least one criterion present in the past 6 months.

With respect to the severity of the disorder, DSM-IV classifies conduct disorders as mild, moderate and severe. This classification is very important, as theoretically speaking (according to current classification systems), it is possible that a 
child who lies runs away from home and is truant from school has the same diagnosis as a child who has robbed a bank with a gun or raped someone.

\section{order \\ Developmental pathways to conduct dis-}

Conduct disorder is a heterogeneous disorder in terms of etiology, course and prognosis, and currently, there is no singular model that would describe the development of the disorder (3). The results of two longitudinal studies investigating the relationship between age and incidence of antisocial behavior in boys conducted in New Zealand (4) and Oregon (5) led to the formulation of developmental taxonomic theory (4). This theory distinguishes two developmental pathways to conduct disorder: childhood-onset and adolescent-onset type. These two pathways have different causes $(4,6)$.

The type of conduct disorder which is most fully described is the childhood-onset type (early starter). This developmental pathway is characterized by behavioral problems that start in preschool or early school age, variable manifestations of behavioral problems and lifelong persistence of antisocial behavior: fights and aggressiveness at the age of four years; theft and dishonesty at the age of ten years; selling drugs and stealing cars at the age of sixteen; robbery and rape at the age of twenty years, and fraud, extortion and abuse of children in their thirties. This subtype is present in $5-10 \%$ of male delinquents and $20 \%$ of female, and is the cause of more than $50 \%$ of juvenile criminal offenses (4, $7)$. Risk factors for early-onset conduct disorder include male gender (8), low verbal intelligence $(9,10)$, difficult temperament (11), comorbidity with ADHD (12). Many of these children have low scores on neuropsychological and memory tests, lower verbal IQ, hyperactivity, impulsiveness and low self-control $(6,10)$. Children with early-onset conduct disorder often come from severely dysfunctional families and have antisocial parents (inconsistent discipline, single parents and / or one teenage parent, mothers with psycho-pathological symptoms who are harsh or prone to abuse or neglect, as well as frequent family conflicts, numerous changes of primary caretakers, low socioeconomic status). Early neuropsychological deficit, together with the interaction between the individual and an inadequate social environment, results in persistent antisocial behavior patterns (10). This category of indivi-duals, even in childhood, loses an opportunity to acquire interpersonal and prosocial skills, so they remain "handicapped" at every other stage of psychosocial development.

In adolescent-onset conduct behavior (adolescent-limited, late starters), antisocial pat-terns are manifested later in life, usually in adolescence or early adulthood. There is no evidence of early or persistent antisocial problems in their personal medical history and their anti-social behavior is unstable and varies in different situations $(4,7)$. However, the frequency and level of violence and delinquency during adolescence may be more pronounced than with the persistent type antisocial behavior. Moffitt suggests that delinquent behavior limited to this age is a form of "delinquency that symbolizes adult privilege and demonstrates autonomy from parental control." The most significant predictors of adolescent delinquency are peer delinquency, attitudes towards adolescence and adulthood that reflect differences in maturity (e.g. desire for independence), social and historical context that affects adolescence and years of age (4). Sometimes the adolescent's behavior, which can include vandalism, drug and alcohol abuse or theft, is in fact the result of adolescent rebellion and a symbol of "reaching adult status." There are usually no problems with the individual's personality or family circumstances. These adolescents develop empathy, avoid peer rejection and are aware of the rewards for socially acceptable behavior and the high price of the delinquent, and are, therefore, able to abandon the delinquent behavior when prosocial behavior starts to offer greater rewards, or due to significant life events (employment, marriage) $(4,7)$. However, pro-blems that persist in adulthood may be the result of antisocial behavior in adolescence (criminal record, school dropouts, drug addiction) $(4,10)$.

\section{Prognosis according to the time of onset}

Childhood-onset and adolescence-onset conduct disorders have different course and prognosis. The prognosis is much worse if the disorder occurs at an earlier age, because it is more often associated with activity and attention deficit disorder, as well as other comorbid disorders. The prognosis is worse in psychosocial terms as well and includes a wide range of antisocial behavior, prison sentences, personality disorders, other mental disorders, substance abuse, as well as poblems at work and in the family. Those who pertain to this subtype often commit violence against women and children and other severely violent acts (7). Problems with physical health, including higher rate of injury, hospitalization, sexually transmitted diseases, smoking and chronic respiratory disease, even violent death, are more common in this group $(13,14)$. Antisocial personality forms slowly and insidiously over the years, while the cumulative negative effects of problems in the young age on the development of personality reduce the possibility of change.

Prognosis in adolescent-onset conduct disorders is not as good as it was previously believed. These individuals are at higher risk for substance abuse and criminal acts in comparison to the average population (13). There are fewer psychosocial risk factors in this group compared to the childhood-onset subtype, but more than the adolescents in the control group (15). Internalizing problems and stress are more common and it is 
not clear whether their problems disappear in adulthood $(13,16)$. According to Moffitt et al. (7) members of the adolescent-onset subtype at the age of 26 years had higher rates of criminal offenses related to drug trafficking and destruction of property, and more symptoms of depression and anxiety on self-report scales in comparison to those without a history of antisocial behavior in childhood and adolescence.

In terms of gender, there are more similarities than differences in the developmental pathways of anti-social behavior patterns and risk factors $(17,18)$. Most females had the so-called delayed onset, with behavior problems that started in adolescence (16). Recent studies, however, also report the group of females with childhoodonset antisocial behavior, with a poor prognosis in adolescence and adulthood (19).

\section{Treatment}

Different developmental pathways together with the heterogeneity of risk factors suggest comprehensive interventions focused on a number of factors. As conduct disorder usually has a chronic course, the effectiveness of short-term therapeutic intervention is very poor (20).

Pharmacotherapy is never applied as first line therapy and is never the only therapy in the treatment of coduct disorders. However, although there is no official medicine for the treatment of conduct disorders, clinicians inevitably face the need to introduce medications in cases when a conduct disorder is accompanied by high aggressiveness and impulsiveness resistant to psychosocial treatment. There is no specific medicine for the treatment of aggressiveness, so medicines which can indirectly reduce aggressiveness are used. Those include atypical antipsychotics, anticonvulsants, mood stabilizers, anxiolytics, beta blockers, alpha agonists, and other psychopharmaceuticals (21). During the application of pharmacotherapy, it is necessary to intensify psychotherapy and psychosocial interventions. Pharmacotherapy is not to be the only treatment of conduct disorders.

Psychotherapy has been and will remain the basis for treating conduct disorders. Recommended interventions for childhood-onset conduct disorder are those which focus on psychoeducation and support to parents and the school in order to avoid encouraging the undesirable behavior. For example, Families and Schools Together is a multi-component program designed for children with severe behavioral problems whose effectiveness has been confirmed in many studies (22). This program includes several interventions such as parenting training, cognitive behavioral training for problem solving and anger management, the implementation of effective strategies to control behavior in schools, mentoring systems, as well as help in improving family functions through regular house visits.

Parenting training programs involve teaching parents individually and in groups to direct attention at and encourage desired forms of behavior, and implement appropriate strategies for reducing inappropriate behavior (23). The techniques include using role-plays and videos to practice new parenting techniques and styles. Studies have confirmed the effectiveness of parenting training programs $(24,25)$. The treatment is ineffective with parents who are not motivated or are not aware of the severity of the disorder, and for those with a psychiatric illness or problems with substance abuse. Comorbid disorders in children, such as ADHD, speech disorder, and failure at school, may also reduce the effectiveness of the treatment.

Multisystemic therapy is recommended for adolescent-onset conduct disorder $(26,27)$. This therapy is based on a range of techniques aimed at improving relationships with individuals, parents, family members and peers. It is based on systemic and structural family therapy, parenting training programs, marital therapy, as well as supportive psychotherapy for improving social skills and interpersonal relations. Functional family therapy is also applied to help change the patterns of family interaction and communication to promote adaptive family functioning.

\section{Conclusion}

The original Moffitt's taxonomy suggests two developmental pathways to conduct disorders: childhood onset conduct disorder that is under greater influence of genetics and adolescenceonset conduct disorder, which is under greater influence of the environment. This kind of classification is important to both researchers and clinicians because it gives them an opportunity to examine the development of the disorder from developmental psychological perspective and conceptualize differentiated approaches to the choice of primary, secondary and tertiary preven-tion. However, the two types of disorders are difficult to diffenrenciate in adolescence, since patients exhibit similar antisocial and delinquent behavior in this age group. On the other hand, medical history may not provide clinicians with reliable data about the emergence of behavioral problems in childhood, which makes it difficult to differenciate between the two subtypes. Recent research suggests that it is necessary to identify other factors which would help to differentiate between these subtypes, such as comorbid hyper-kinetic disorder, biomarkers, family history and antisocial traits, especially callous-unemotional traits (6) to allow for an individualized approach, assessment and high-quality treatment 


\section{References}

1. Svetska zdravstvena organizacija. ICD-X Klasifikacija mentalnih poremećaja i poremećaja ponašanja. Klinički opisi i dijagnostička uputstva. Beograd: Zavod za udžbenike i nastavna sredstva; 1992.

2. American Psychiatric Association. Diagnostic and statistical manual of mental disorders, 4th ed. Washington, DC: American Psychiatric Press; 1994.

3. Frick PJ. Development Pathways to Conduct Disorder: Implications for Future Direction in Research, Assesment, and Treatment. J Clin Child Adolesc 2012; 41(3): 378-89. [CrossRef] [PubMed]

4. Moffitt TE. Adolescence-Limited and Life-CoursePersistent Antisocial Behavior: A Developmental Taxonomy. Psychol Rev 1993; 100(4): 674-701. [CrossRef] [PubMed]

5. Patterson GR, Capaldi D, Bank L. An early starter model for predicting delinquency. In: Pepler DJ, Rubin $\mathrm{KH}$, editors. The Development and Treatment of Childhood Aggression. Hillsdale, NJ: Lawrence Erlbaum Associates; 1991.

6. Moffitt TE, Arseneault L, Jaffee SR, Kim-Cohen J, Koenen KC, Odgers CL, et al. Research Review: DSM$\checkmark$ conduct disorder: research needs for an evidence base. J Child Psychol Psyc 2008; 49(1): 3-33. [CrossRef] [PubMed]

7. Moffitt TE, Caspi A, Harrington H, Milne B. Males on the life-course persistent and adolescent limited antisocial pathways: Follow-up at age 26. Dev Psychopathol 2002; 14(1): 179-206. [CrossRef] [PubMed]

8. Zoccolillo M. Gender and the development of conduct disorder. Dev Psychopathol 1993; 5: 65-78. [CrossRef]

9. Farrington DP. Understanding and preventing bullying. In: Tonry M, editor. Crime and justice, Vol. 17, pp. 381-458. Chicago: University of Chicago Press; 1993. [CrossRef]

10. Moffitt TE, Caspi A. Childhood predictors differentiate life-course persistent and adolescence-limited antisocial pathways among males and females. Dev Psychopathol 2001; 13(2): 355-75. [CrossRef] [PubMed]

11. Olson SL, Bates JE, Sandy JM, Lanthier R. Early developmental precursors of externalizing behavior in middle childhood and adolescence. J Abnormal Child Psych 2000; 28 (2): 119-33. [CrossRef] [PubMed]

12. Lahey BB, McBurnett $K$, Loeber R. Are attention deficit/ hyperactivity disorder and oppositional defiant disorder developmental precursors to conduct disorder? In: Sameroff AJ, Lewis M, Miller SM, editors. Handbook of developmental psychopathology, 2nd edition, pp. 431-46. New York: Kluwer Academic; 2000. [CrossRef]

13. Odgers CL, Caspi A, Broadbent JM, Dickson N, Hancox RJ, Harrington $\mathrm{H}$, et al. Prediction of differential adult health burden by conduct problem subtypes in males. Arch Gen Psychiat 2007; 64(4): 476-84. [CrossRef] [PubMed]

14. Piquero AR, Gibson LE, Daige C, Piquero NL, Tibbetts SG. Research Note Are Life-Course-Persistent Offenders At Risk for Adverse Health Outcomes? J
Res Crime Deling 2007; 44(2): 185-207. [CrossRef]

15. Fergusson DM, Lynskey MT, Horwood LJ. Childhood sexual abuse and psychiatric disorder in young adulthood: I. Prevalence of sexual abuse and factors associated with sexual abuse. J Am Acad Child Adolesc Psy 1996; 35(10): 1355-64. [CrossRef] [PubMed]

16. Pitzer M, Esser G, Schmidt MH, Laucht M. Early predictors of antisocial developmental pathways among boys and girls. Acta Psychiat Scand 2010. 121(1): 52-64. [CrossRef] [PubMed]

17. Martino SC, Ellickson PC, Klein DJ, McCaffrey D, Edelen MO. Multiple trajectories of psysical aggression among adolescent boys and girls. Aggressive Behav 2008; 34(1): 61-75. [CrossRef] [PubMed]

18. Moffitt TE, Caspi A, Rutter M, Silva PA. Sex differences in antisocial behaviour: Conduct disorder, delinquency, and violence in the Dunedin Longitudinal Study. Cambridge: Cambridge University Press; 2001. [CrossRef]

19. Javdani S, Sadeh N, Verona E. Expanding our Lens: Female Pathways to Antisocial Behavior in Adolescence and Adulthood. Clin Psychol Rev 2011; 31(8): 1324-48. [CrossRef] [PubMed]

20. Kazdin $A E$, Weisz JR, editors. Evidence-based Psychotherapies for Children and Adolescents. New York: Guilford Press; 2003.

21. Pappadopulos E, Woolston S, Chait A, Perkins M, Connor FD, Jensen PS. Pharmachotheraphy of aggresion in children and adolescents: efficacy and effect size. J Can Acad Child Adolesc Psychiatry 2006; 15(1): 27-39. [PubMed]

22. Bierman $\mathrm{KL}$, Coie JD, Dodge $\mathrm{KA}$, Foster $\mathrm{EM}$, Greenberg MT, Lochman JE, McMahon RJ, Pinderhughes EE; Conduct Problems Prevention Research Group: The effect of the FAST Track Program of serius problem outcomes at the end of the elementary school. J Clin Child Adolesc Psychol 2004; 33: 650-61. [CrossRef] [PubMed]

23. Weisz JR, Sandler IN, Durlak JA, Anton BS. Promoting and protecting youth mental health through evidence-based prevention and treatment. Am Psychol 2005; 60(6): 628-48. [CrossRef] [PubMed]

24. Webster-Stratton C, Reid MJ, Hammond $M$. Preventing conduct problems, promoting social competence: A parent and teacher training partnership in Head Start. J Clin Child Psychol 2001; 30(3): 238-302. [CrossRef] [PubMed]

25. Scott S, Spender Q, Doolan M, Jacobs B, Aspland H. Multicentre controlled trial of parenting groups for child antisocial behaviour in clinical practice. BMJ Brit Med J 2001; 323(28): 1-5. [PubMed]

26. Curtis NM, Ronan KR, Borduin CM. Multisystemic treatment: A meta analysis of outcome studies. J Fam Psychol 2004; 18(3): 411-9. [CrossRef] [PubMed]

27. Farrington DP, Welsh BC. Family-based prevention of offending: a meta-analysis. Aust NZ J Criminol 2003; 36(2): 127-51. [CrossRef] 


\title{
RAZVOJNA TAKSONOMSKA TEORIJA POREMEĆAJA PONAŠANJA
}

\author{
Jelena Kostić ${ }^{1}$ Milkica Nešić2 , Jasminka Marković3, \\ Miodrag Stanković ${ }^{1}$
}

\author{
Klinika za zaštitu mentalnog zdravlja, Klinički centar Niš, Niš, Srbija ${ }^{1}$ \\ Univerzitet u Nišu, Medicinski fakultet u Nišu, Institut za fiziologiju, Srbija ${ }^{2}$ \\ Centar za dečju i adolescentnu psihijatriju, Institut za psihijatriju, \\ Klinički centar Vojvodine, Novi Sad, Srbija ${ }^{3}$ \\ Kontakt : Jelena Kostić \\ Bul. Zoran Đinđic 48, 18000 Niš, Serbia \\ E-mail: jelenakostic73@gmail.com
}

Poremećaj ponašanja je heterogeni poremećaj u pogledu etiologije, toka i prognoze i za sada ne postoji jedinstveni model koji bi opisao razvoj poremećaja. Rezultati empirijskih istraživanja na populaciji muškog pola potvrđuju ovu heterogenost, jer izdvajaju dve putanje razvoja poremećaja ponašanja: poremećaj ponašanja sa početkom u detinjstvu i poremećaj ponašanja sa početkom u adolescenciji. $U$ radu su dati osnovni elementi razvojne taksonomske teorije koja zastupa stanovište da se poremećaj ponašanja može okarakterisati dvema različitim razvojnim putanjama u čijim osnovama leže različiti uzroci, a koji su poslužili kao osnova za aktuelnu tipologiju poremećaja ponašanja u klasifikacionim sistemima. Ovakva tipologija poremećaja ponašanja u dijagnostičkim klasifikacijama omogućava bolje razumevanje, prognostičko sagledavanje i izbor tretmana poremećaja. Acta Medica Medianae 2015;54(4):79-83.

Ključne reči: poremećaj ponašanja, deca, adolescenti

This work is licensed under a Creative Commons Attribution 4.0 International (CC BY 4.0) Licence 